\section{Journal of Applied Phycology}

December 2006, Volume 18, Number 6 : Pages 741-

755

http://dx.doi.org/10.1007/s10811-006-9083-1

(c) 2006 Springer. Part of Springer Science+Business Media
Archimer, archive institutionnelle de l'Ifremer http://www.ifremer.fr/docelec/

\title{
Anaerobic Digestion of Ulva sp. 3. Liquefaction Juices Extraction by Pressing and a Technico-Economic Budget
}

\author{
Philippe Morand ${ }^{1,6,{ }^{*}}$, Xavier Briand ${ }^{2,3}$ and Roger H. Charlier ${ }^{4,5}$
}

\footnotetext{
${ }^{1}$ Centre de Recherche en Ecologie marine et Aquaculture, CNRS-IFREMER, 17137 L'Houmeau, France

${ }^{2}$ Centre d'Étude et de Valorisation des Algues, 22610 Pleubian, France

${ }^{3}$ Present address: SECMA, BP 65, Z.I., 22660 Pontrieux, France

${ }^{4}$ Institute for Development, Research, and Enquiry in Coastal Zone Studies, 4055 North Keystone Avenue, Chicago, IL, 60641-2414, U.S.A.

${ }^{5}$ Present address: avenue du Congo [box 23], Brussels, B-1050, Belgium

${ }^{6}$ UMR 6553, CNRS-Université de Rennes 1, Station Biologique, 35380 Paimpont, France
}

\begin{abstract}
*: Corresponding author : P. Morand, Phone: +(33) 299.61.81.77, Fax: +(33) 299.61.81.87, email address : philippe.morand@univ-rennes1.fr
\end{abstract}

\begin{abstract}
:
In many countries, the algae of "green tides" are harvested in the fight against pollution. Ulva often represents the main component of the tide, and intensive research has been conducted on the possibility to use the algae as a methanisation substrate. However, methanisation is hampered by various practical obstacles, which requires a compromise between productivity and biological yield.

The process described here calls upon a pre-digestion phase of Ulva which, besides the economy of time and volume of the digestion, makes it possible to obtain a biogas of good quality. The methanisation substrate is the hydrolysis juice collected by draining, followed by pressing. The cake resulting from the pressing process can be used as organic enriching or fertilizing agent in agriculture. Various presses were tested. The screw press was found the most suitable to recover a great quantity of sufficiently loaded pressing juice after only a short hydrolysis time. For a 3 month hydrolysis period, the different fractions amounted to $158 \mathrm{~L}$ of hydrolysis juice, $192 \mathrm{~L}$ of pressing juice, and $0.075 \mathrm{~m}^{3}$ of cake per $\mathrm{m}^{3}$ of initial algae.

The bi-phasic anaerobic digestion with forced recuperation of juices offers interesting pollution abatement perspectives, with total and soluble chemical oxygen demand cleaning rates of respectively 79 and $95 \%$ during the methanogenic phase, for a volume productivity of $1.5 \mathrm{~m}^{3} \mathrm{CH}_{4} \mathrm{~m}^{-3}$ digester day $^{-1}$. The quality of the Ulva juice also makes it suitable for use as substrate for industrial processes or co-substrate of methanisation in pre-existing reactors, so that subsequent investment could be avoided.
\end{abstract}

Keywords: acidogenesis - drift algae - green tides - methanisation - pressing juice - VFA 


\section{Introduction}

The excessive growth of some opportunist seaweeds in reaction to medium disturbance is observed with increasing frequency in coastal ecosystems close to agricultural or strongly urbanized and industrialized zones (Fletcher, 1996; Morand and Briand, 1996). These seaweed proliferations are still badly managed, though numerous studies have shown the direct involvement of nitrogen and phosphorus (de Jonge et al., 2002; Morand and Merceron, 2004).

The environmental impact can be assessed in terms of organic load, nitrogen, phosphorus and hydrogen sulphide pollution. Seventy percent of the nitrogen and $63 \%$ of the phosphorus of the stranded seaweed are mineralized after 7 weeks (Morand and Briand, 1999). Were the $11000 \mathrm{t}$ of Ulva stranded in Lannion Bay to decompose on the coast, the total amount of nutrients recycled in the ecosystem could be estimated at $20 \mathrm{t} \mathrm{N}$ and $2 \mathrm{t} \mathrm{P}$, with an initial composition of Ulva being on the average $20 \mathrm{mg} \mathrm{N} \mathrm{g}^{-1}$ dry matter and $0.2 \mathrm{mg} \mathrm{P} \mathrm{g}^{-1}$ dry matter (Briand and Morand, 1997). Such quantities can be compared to urban pollution. Renewed three times in one year, they correspond to the annual wastes generated by a city of more than 12,000 inhabitants such as Lannion. Most nitrogen and phosphorus released is in dissolved mineral form and thus potentially usable to maintain the level of biomass production. Surmising that these amounts would be entirely available for Ulva growth, the recycling would cover $60 \%$ of the needs necessary to maintain the production level.

To these, ought to be added a production of $50000 \mathrm{~m}^{3} \mathrm{H}_{2} \mathrm{~S}$, as estimated according to the work of Wilkinson (1963). The Ulva harvest and its treatment appear, in the light of these observations, as an absolute necessity (Charlier and Morand, 2005).

The interest for green seaweeds bioconversion by anaerobic fermentation encompasses therefore linking pollution abatement and energy production. However, we have shown that the methanisation of the entire seaweed has a disadvantage as it requires a digester of significant size, hardly compatible with an acceptable economic return (Briand and Morand, 1997). Similarly, the hydrolysis of the entire seaweed, directly followed by methanogenesis, i.e. the methanisation of Ulva separated in two steps, with natural recovery of the liquefaction juice, also stumbles on the economic obstacle, because the time for hydrolysis is long, thus resulting in a high cost of the process (Morand and Briand, 1999).

In the course of the processing of Ulva sp. by fermentation, a solid/liquid separation, which would occur between the acidogenic and methanogenic phases, would allow the extraction of the organic pollution to be assured. The results of pollution abatement and energy production would depend on its effectiveness. Technologically, the devices permitting this solid/liquid separation, excluding centrifugation, generally combine filtration with mechanical compression. The extraction obtained depends then on its resistance of the substrate to filtration. It depends also on operating parameters (Baskerville et al., 1971). The equipment for extraction will have therefore to be adapted to the constraints imposed by the two fermentations: quality of the substrate stemming from the acidogenic fermentation, and suitability of the filtrate as regards the parameters governing the methanic fermentation. This equipment will also have to be sufficiently easy to operate. The size reduction of the particles contained in the juice must render the substrate more accessible to attack by microorganisms. An improvement of the cleavage of the polymers in metabolites will follow and, thence, of the rate of pollution abatement. Moreover, this will permit to avoid, during processing in a fixed cells reactor (bacterial filter), the formation of a deposit of the suspended solids inside the reactor.

Attempts at separation solid/liquid were already made on similar substrates. For instance, Reid and Jackson (1956) get a pressing cake of Ascophyllum nodosum (Linnaeus) Le Jolis, fit for agricultural use, by drying the algae with a press band filter. Pretreatments of the Venice Lagoon algae (Ulva rigida C. Agardh, Gracilaria verrucosa (Hudson) Papenfuss, Valonia aegagropila C. Agardh, and Chaetomorpha aerea (Dillwyn) Kützing) were studied, including grinding, pressing and centrifugation (Missoni and Mazzagardi, 1985). Orlandini and Favretto (1988) reported such an experiment, where centrifugation was used on ground algae in order to obtain a liquid substrate to be methanized, which contained $50 \%$ of the original organic matter.

During the work presented here, we therefore sought to determine whether it was possible, at first, to perform a hydrolysis under natural conditions on an area adapted in the simplest possible manner and, next, to extract faster the hydrolysis juice. We tested solid/liquid separation by way of centrifugation or pressing. The methanisation of the juice obtained was then assessed. In fine, this study allowed us to sum up the technical and economic balance of a possible method to handle the Ulva green tides scourge. 


\title{
2. Materials and methods
}

\author{
Substrate: Ulva \\ Algae used had the characteristics described by Briand and Morand (1997).
}

\section{Acidogenic reactor}

A reactor was specially devised for the study of hydrolysis under natural conditions and in full size: a sheet was stretched over a $208 \mathrm{~m}^{2}$ surface and then raised to a height of $2 \mathrm{~m}$ at the sides. The evacuation of the juices and their quantification were achieved by a draining system and an outflow into a pit. This storage area followed the model of the storage tank (cf. Morand and Briand, 1999). Its capacity was $400 \mathrm{~m}^{3}$. During the 7 months of acidogenic fermentation, the production of juice, the chemical characteristics of the effluents (COD, $\mathrm{NH}_{4}{ }^{+}, \mathrm{pH}$ ) and the deposit (TS, VS, C, N, P, K, Na) were determined every 15 days.

\section{Presses and centrifuges for solid/liquid separation}

Functioning of the different laboratory and industrial materials used is described below, some of them shown in figure 1.

Laboratory tray-press. In the tray-press (Figure 1a), the solid/liquid separation is performed under a pressure exerted on a filter by a downward moving piston. The filtering element is a steel plate with $2 \mathrm{~mm}$ holes, whereupon a $200 \mu \mathrm{m}$ mesh metallic cloth is placed. The hydraulic pressure can be set by the operator within an area of approximately 0 to 100 bar, which corresponds -- taking into account the geometrical characteristics of the press -- to a pressure exerted on the pressed substance of 0 to 50 bar. The piston's surface is $320 \mathrm{~cm}^{2}(160 \times 200 \mathrm{~mm})$. The matter being saturated in liquid, a certain amount of this liquid tends to flow freely. There is therefore, at first, a filtration phase under atmospheric pressure. The piston is thereafter lowered. While the juice begins to flow, pressing occurs at constant speed. Then, as the resistance of the cake increases considerably, the pressing speed decreases, and the pressure increases until the maximal value set by the operator is reached, leading to pressing at constant pressure.

Laboratory centrifuge (Kontron Centrikon H401). The separation takes place in $500 \mathrm{ml}$ flasks. Under centrifugal action, heavy particles decant and settle against the side. The possible maximal acceleration is $14725 \mathrm{~g}$.

Centrifuge (Guinard). The suspension to be processed is introduced through a stationary tube in a rotating distributor which distributes it to the edge (Figure $1 \mathrm{~b}$ ). Under centrifugal action, heavy particles decant and deposit against the internal wall of the bowl. Scraped by a conveying screw, they are continuously carried to a cone. The sediments compressed in the cone are evacuated through orifices provided for the purpose. The continuous feeding permits the liquid's evacuation through outpourers.

Screw-press (Speichim 100 and Tasster). The continuous presses Speichim and Tasster (Figure 1c) are equipped with endless screws insuring the dual function of feeding and pressure. The section of the exit-orifice of the spun-dry products can be varied by axial moving of an obturating cone. Underneath the exit orifice, a porous nose allows maximal drying of the residue by facilitating the flow of juices from the press's exit (Tasster press solely). During extraction, the Tasster press also exerts self-pressing which, combined with the pressure applied against the hole, can reach 30 bar, depending on the product's texture. The pressure exerted by the Speichim press is limited to 1.5 bar.

Pressing band filter (Exofort Guinard). Filtration is done in two steps, first in an average pressure stage, next in a high pressure stage (Figure 1d). The mud is deposited in a draining unit. Thereafter the mud move between two cloths and is gradually compressed by a roller covered with fitted tees facilitating filtrates' evacuation to the sides, then by a roller with holes, a solid roller, a tension roller, three average pressure rollers and finally a roller on which the cloths separate and liberate the mud 
that then falls onto a moving evacuation band. Two rakes detach the mud particles adhering to the cloths. The washing of the cloths is insured by 2 ramps.

Filter with membrane (Hyperpresse - General Sucrière). The Hyperpresse (Figure 1e) results from the association of two techniques: the multi-layered pressing and the radial pressing with membrane. The radial pressing of a cylindrical cake is achieved by the unwinding onto a spool of a mud-loaded cloth.

\section{Solid/liquid separation}

For each experiment, the initial dry matter of the algae mud was determined before pressing or centrifugation, and juice and cake obtained were analysed to get the budget for matter and to determine the extraction yields. The extraction yields are calculated as the ratio of the soluble COD in the juice and in the initial mud, corrected by the ratio of the water content in the initial mud and in the juice.

Laboratory tray-press. Hydrolysis mud (1 or $2 \mathrm{~kg}$ approximately) was introduced into the press after homogenisation. Tests were carried out over a period of $5 \mathrm{~min}$, after which the piston was raised. Time 0 corresponds to the flow of the first drop of liquid during the pressing phase.

Laboratory centrifuge. In each of six centrifugation tubes (500 ml), approximately $225-230 \mathrm{~g}$ of brokendown seaweeds were deposited. Centrifugation was performed at 1000 to 9000 turns min $^{-1}$ (1130 to $10,200 \mathrm{~g}$ approximately) at different times. The extraction yields and the residue density were evaluated for each case.

Continuous flow centrifuge. Taking into account the equipment constraints imposed by industrial vegetables, tests were made at a centrifugal speed of 4000 turns $\mathrm{min}^{-1}$, or the equivalent of an acceleration of approximately $2000 \mathrm{~g}$, during $2.5 \mathrm{~min}$, the weight of treated substrate being then $5 \mathrm{~kg}$.

Screw-press. Tests were undertaken with the Tasster (ALSTHOM NEYRTEC) press at different speeds (of 3 to 10 turns $\mathrm{min}^{-1}$ ) and at different pressures (1 to 10 bar). The treatment involved 500 to $2000 \mathrm{~kg}$ of seaweed stored during 3 or 7 months.

Pressing band filter. After eight months of hydrolysis, $80 \mathrm{~kg}$ of seaweeds were processed by the pressing band filter under the following conditions: - speed of the cloth's passing: $1 \mathrm{~m} \mathrm{~min}^{-1}$; - operating pressure: 10 bar; - thickness of layer: $0.03 \mathrm{~m}$; - width of cloth: $0.30 \mathrm{~m}$; - output: $0.55 \mathrm{t} \mathrm{h}^{-1}$.

Hyperpress. The machine test was carried out after 7 months of storage, on $260 \mathrm{~kg}$ of broken-down algae. The behaviour of the seaweed (extraction kinetics and quantity of extracted juice) was studied according to a prior established pressure rise kinetics. The final pressure of 50 bar was obtained after $23 \mathrm{~min}$ of the experiment and maintained until the $40^{\text {th }}$ minute. The width of cloth was $0.30 \mathrm{~m}$.

\section{Juices anaerobic digestion}

The methanogenic fermentation was carried out at $35^{\circ} \mathrm{C}$ in the bacterial fixed bed reactor described in Morand and Briand (1999), which functioned, before the introduction of juice, with liquid hog manure (dry matter: $44 \mathrm{~g} \mathrm{~L}^{-1}$, organic matter: $25 \mathrm{~g} \mathrm{~L}^{-1}$, ammonia water: $5 \mathrm{~g} \mathrm{~L}^{-1}$ ).

Taking into account significant ammonia concentrations, the manure was diluted by 3 with the filtrate. During the first three days, the volumetric load was set at $1.5 \mathrm{~g} \mathrm{VS} \mathrm{L}^{-1} \mathrm{~d}^{-1}$ (RT $=20$ days), passing subsequently to $3 \mathrm{~g} \mathrm{VS} \mathrm{L}^{-1} \mathrm{~d}^{-1}$ (RT = 10 days). From the tenth day on, the supply was made up solely of juice. During the experimentation's duration, the $\mathrm{pH}$, the COD entering and leaving the digester were studied daily. Concurrently, the volume and quality of the biogas produced $\left(\mathrm{CO}_{2}, \mathrm{CH}_{4}\right)$ were controlled. Once the production stabilized, the budget was drawn-up for two times of retention.

\section{Analytic methods}

After Briand and Morand (1997). 
The presented results correspond to an average of analyses performed on six samples of algae or Ulva mud. Juice or cake were homogeneous before analysis.

\section{Results}

Hydrolysis in a fitted pit

In the course of seven months of acidogenic fermentation on an area of storage of $400 \mathrm{~m}^{3}$, the hydrolysis kinetics was very slow (Figure 2). Climatic conditions prevailing during the first four months of storage, leading, by instance, to freezing on $0.60 \mathrm{~m}$ of seaweeds deposit, in January, slowed considerably the activity of the bacterial flora. With the return to milder climatic conditions, it was not possible for the hydrolytic phase to restart. At the end of the storage period, the recorded rate of energy recovery of the substrate was only $1.56 \%$. The strong volumetric productivity in juice (Figure $2 \mathrm{a}$ ) is explained by the high precipitations recorded in the course of this period.

The utilization of a simple agricultural sheet to cover the bottom of the pit for the seaweeds storage proved to be an error. Despite precautions taken in the course of loading, the sheet was damaged by trucks, sliding of deposits, frost, and so on. From then on, the sheet being no longer evenly distributed, pockets and preferential passages formed with juice evacuation partly at the sheet's tears.

This test, undertaken under difficult conditions, since the normal period for effective seaweed gathering by municipalities is Summer, and on a non-stabilized and not really "waterproof" storage area, showed that the natural liquefaction with recovery of hydrolysis juice was a system too dependent on climatic and weather conditions, on the load density, and on the quality of the dumping terrain. This last point excluded a rapid and low cost set-up. The demonstration of the necessity to turn towards a system of faster processing (centrifugation or pressing) was thus made.

\section{Determination in laboratory of some parameters to be applied to an industrial centrifuge or press}

Centrifugation. Tests were conducted with different rotation speeds (1000 to 9000 turns $\mathrm{min}^{-1}$ ) and times of centrifugation $(2,5,15,30$ and $60 \mathrm{~min})$. Under the effect of centrifugal force, suspended solids underwent accelerated decantation and were packed against the wall of the bowl. The sedimentation was relatively rapid, but good dehydration required high rotation speeds. The maximal drainage rate of $63.2 \%$ was reached at the maximal speed and time tested, i.e. 9000 turns $(10,200 \mathrm{~g})$ and $60 \mathrm{~min}$.

Pressing. An approach to the extraction kinetics according to the pressure and Ulva mud mass conditions was undertaken by means of laboratory unit for compression-filtration (tray press).

In order to evaluate the cake's thickness influence, two tests were done under the same pressing speed and pressure conditions $\left(0.35 \mathrm{~mm} \mathrm{~s}^{-1}, 5\right.$ bar), trial 1 with an initial load of $0.610 \mathrm{~g} \mathrm{TS} \mathrm{cm}^{-2}$ corresponding to a cake thickness of $12 \mathrm{~mm}$ at the end of pressing, trial 2 with an initial load of $1.282 \mathrm{~g} \mathrm{TS} \mathrm{cm}^{-2}$ corresponding to a cake thickness of $32 \mathrm{~mm}$ at the end of pressing. A slight cake thickness had a beneficial influence on the pressing result (Figure 3a). For a layer of $12 \mathrm{~mm}$, the dryness went from 19.4 to $38.5 \%$, that is to say a gain of $19 \%$, while it is only of $12 \%$ when the cake thickness is of $32 \mathrm{~mm}$ (Table 1). Moreover, the leaching of sodium and potassium salts was clearly less important for a layer thickness of $32 \mathrm{~mm}$. The cake itself was made up of two layers; one, at the filtering element contact, was very compact, which did not permit the draining of the other layer. Thus, for high pressing efficiency, it appears indispensable to work with very thin thicknesses of cake.

The influence of pressure has therefore been studied for a layer thickness of $12 \mathrm{~mm}$ (weight of matter: $1000 \mathrm{~g}$ ). Trial 3 has been done under a pressure of 25 bar. The cake dryness was far more significant when the pressing was carried out under strong pressure (Table 1). The result obtained shows a priori the order of magnitude of optimal dryness possible to be reached with this type of matter. This improvement of the cake dryness was also shown by an increase in the extraction yields of soluble salts, a. o. sodium, potassium, which passed respectively from 52 and $54 \%$ to 73 and $69 \%$. Similarly, the extraction of soluble chemical oxygen demand tended towards its optimum (100\%) while, in test 1 , it reached only $80 \%$.

In figure $3 b$, the mass flow of juice is given as a function of time for trials 1 and 3 . This flow reached a maximum, then decreased rapidly and tended towards a negligible value. As regards the juices composition, it was appreciably comparable in the three trials. The suspended solids and the dryness 
were respectively in the order of 15 and $41 \mathrm{~g} \mathrm{~L}^{-1}$. The concentrations of total chemical oxygen demand $\left(\mathrm{COD}_{\mathrm{t}}\right)$ and of soluble chemical oxygen demand $\left(\mathrm{COD}_{\mathrm{s}}\right)$ were respectively in the order of 25 and $15 \mathrm{~g}$ $\mathrm{L}^{-1}$.

Study of the performances of different industrial equipments for liquid/solid separation

Different equipments such as the screw-press, the pressing band filter, the filter press, the rotary filter, the membrane press, and the centrifuge have been considered for extraction of the Ulva juice after hydrolysis. Preliminary work allowed to rule out the use of equipment such as rotary filter, filter press, or tray press (not fitted for industrial use, in spite of the good results in laboratory).

For each of the remaining equipment, with respect to the different experimental conditions, the budget for matter was established according to the characteristics of the product before and after processing, allowing, on the one hand, efficiency to be evaluated for the drainage and extraction of the chemical oxygen demand (COD) and, on the other hand, losses in the different components to be assessed (Table 2). Extraction quality was checked by analysis of the press filtrates.

Centrifuge. The experimentation was carried out under an acceleration of $2000 \mathrm{~g}$ during $2 \mathrm{~min}$. The initial product's TS concentration was $143 \mathrm{~g} \mathrm{~L}^{-1}$. After centrifugation, the final dryness of the pellet reached $25 \%$, to wit a gain of 10 points. The drainage rate of $47 \%$ with a $\mathrm{COD}_{\mathrm{s}}$ extraction yield of $30 \%$ only seems not sufficient to justify this technique's use at an industrial level. As on the laboratory scale, far larger accelerations should be reached in order to obtain a worthwhile result. Furthermore, the presence of sand is a significant risk of wear-down for great speed rotating parts. These reasons force abandon of centrifugation as separation technique.

Screw press. The Tasster press was subjected to numerous trials, by varying the initial substrate (ulvae having undergone a 3- or 7-month hydrolysis) and pressure and screw rotation speed conditions.

The hydrolysis time increase from 3 to 7 months entrained a drop in extraction yield, from $89-99 \%$ to $60-80 \%$, while the SS rate surged from $40-97 \mathrm{~g} \mathrm{~L}^{-1}$ to $85-148 \mathrm{~g} \mathrm{~L}^{-1}$ in the filtrates. The loss of volatile fatty acids (VFA) through evaporation during the acidogenic fermentation affected filtrate quality: the $\mathrm{COD}_{\mathrm{s}}$ concentration went from $15-38 \mathrm{~g} \mathrm{~L}^{-1}$ down to $6-12 \mathrm{~g} \mathrm{~L}^{-1}$.

Screw rotation speed did not influence the extraction yield. On the other hand, an increase in SS content followed normally an increase in screw rotation speed. For instance, with the 3-month algae and under a 3-bar pressure, the SS rate thus passed from $64 \mathrm{~g} \mathrm{~L}^{-1}$ to $97 \mathrm{~g} \mathrm{~L}^{-1}$ between 3 and 10 turns $\mathrm{min}^{-1}$. Pressure increase influenced little the extraction yield, but caused generally a highest SS concentration in the filtrate, as a result of the crushing effect caused by the press. The 3-month trial run under the 3-bar pressure with a rotation speed of 10 turns $\mathrm{min}^{-1}$ provided, notwithstanding a rather high SS rate $\left(97 \mathrm{~g} \mathrm{~L}^{-1}\right)$, a good compromise between the extraction yield (99\%) and the discharge. The $\mathrm{COD}_{\mathrm{t}}$ and $\mathrm{COD}_{\mathrm{s}}$ concentrations, respectively 60 and $38 \mathrm{~g} \mathrm{~L}^{-1}$, represented the best results.

Pressing band filter. The pressing band filter provided performance quite close to those of the laboratory trials with a plates press. Indeed it has the advantage of working under high pressure and upon thin layers. Notwithstanding the long hydrolysis time of the tested algae (7 months), the dryness increase during pressing reached $26 \%$ for a final dry matter of $43 \%$, and the extraction yield was high (80\%), the effluent's $C O D_{t}$ climbing to $35 \mathrm{~g} \mathrm{~L}^{-1}$, of which $60 \%$ of $C O D_{s}$, i.e. $21 \mathrm{~g} \mathrm{~L}^{-1}$. The first element is particularly determining for the cake utilization in agriculture. The second is interesting for the global (including methanisation) system's productivity, all the more since the filtrate contained a very small SS rate $\left(18.2 \mathrm{~g} \mathrm{~L}^{-1}\right)$.

Membrane press. The membrane press was tested with a sample that was particularly loaded in dry matter, due to the heterogeneity in the storage area. The load density was $8.81 \mathrm{~kg} \mathrm{~m}^{-2}$ of wet product, and therefore $2.71 \mathrm{~kg} \mathrm{~m}^{-2}$ of dry product. Nevertheless, excellent results in drying were obtained (dryness passed from 31 to $54 \%$ during pressing).

Problems encounter at trial, specifically the difficulty to get a homogenous and thin layer, the trend to mud fluxing and the closing starting at 15 and 30 bars, precluded progressing further than these first data. A problem also existed with pebbles at cloths level (perhaps due, in this case, to the particularly high mineral load of the sample). 
These difficulties however, linked to the current machine equipment, do not put in question this technology, considering the quality of its drying performance. This set-up would certainly require additional experimenting.

The performances efficiency of the various materials tested (tray press, centrifuges, screw presses, membrane press and pressing band filter) may be defined in function of the main criteria of juices output, $\mathrm{COD}_{\mathrm{s}}$ extraction yield and SS rate in the filtrate. Thus, concerning the juice output, the pressing band filter and the screw press exceeded $80 \%$. The centrifugal separation filter technique, providing a drying rate in the $50 \%$ range, is consequently excluded in the treatment of Ulva sp.

The membrane press, too difficult to be mastered with the equipment tested here, was also abandoned for the follow-up of this study.

For a same product texture, if the pressing band filter and the screw press provided similar $\mathrm{COD}_{\mathrm{s}}$ extraction rates, they otherwise had essential differences as far the filtrate was concerned. With the screw press, concomitant with compression, there is a mechanical crushing effect resultant in substantial organic matter losses of the substrate. The SS rate exceeded then $100 \mathrm{~g} \mathrm{~L}^{-1}$ in the juice obtained after 7 months of hydrolysis, while it was barely about $20 \mathrm{~g} \mathrm{~L}^{-1}$ for the pressure band filter filtrate. These losses are however less when the algae were pressed before three months had elapsed.

Budget of the hydrolysis and screw press and band filter juices pressing

The constraints related to the solid/liquid separation material's availability did not enable to carry out the entire range of trials upon an equally old substrate; it was necessary to compare, under such conditions, the two presses which had been retained, and to assess the entirety of acidogenic fermentation and juice extraction.

To that end, the hydrolysis of 14 tons of Ulva was undertaken in an acidogenic fermenter of $30 \mathrm{~m}^{3}$. The production of juice, recuperated by percolation, and its load in $\mathrm{COD}_{s}$ and ammonia water were determined daily. The physico-chemical evolution of the deposit was followed periodically in the course of hydrolysis. At the close of 3 months of acidogenic fermentation, the pressing tests with the screw press (Tasster) and the pressing band filter were carried out simultaneously. The pressing cakes and the juices were analysed in the same way.

Hydrolysis. The Ulvae's physico-chemical characteristics during the hydrolysis phase are given in table 3. As it was the case in the preceding experimentation (Morand and Briand, 1999), the sodium and potassium salts removal was fast and important and involving some $70 \%$ of the original matter. Contrarily, the phosphorus losses remained small (18\% of the original matter) and this notwithstanding a carbon and nitrogen degradation rate of $40 \%$. The juices production was practically linear from the $8^{\text {th }}$ to the $88^{\text {th }}$ day. The COD and ammoniacal nitrogen juices' production kinetics evolved in a manner entirely similar to those observed before during natural liquefaction. The environment's buffer effect sufficed to control VFA production; hence, after having decreased up down 6.9 at the end of the $3^{\text {rd }}$ week, the $\mathrm{pH}$ came up regularly to 7.6. At fermentation's completion, only $3.36 \mathrm{~L}$ of hydrolysis juice at a mean titration of $C^{2} D_{t}$ of $11 \mathrm{~g} \mathrm{~L}^{-1}$ were collected per $\mathrm{kg}$ VS. The soluble fraction represented $89 \%$ of the total. At that stage, $38 \mathrm{~kg} \mathrm{COD}$ and $1.1 \mathrm{~kg}$ of ammoniacal nitrogen were recuperated, and the recuperation rate of substrate energy was only $3.4 \%$, which corresponds to a production of $13.4 \mathrm{~L} \mathrm{CH}_{4}$ $\mathrm{kg}^{-1} \mathrm{VS}$. The deposit weight went down to 5.65 tons.

As far the quality of the Ulva deposit is concerned, it seems that there is a significant change between 4 and 6 weeks. In fact, in spite of big standard deviations, due to the heterogeneity of the deposit (sand presence, local initial state of the algae, ...), it is the time when the dry matter and the volatile solids were close to the maximum, very likely because of the lixiviation occurring during the first month. The sudden density increase conveys probably a deposit modification consecutive to the Ulva structure degradation.

Pressing. The Tasster screw press (SP) and pressing band filter (PBF) tests were performed respectively on substrate amounts of 125 and $1050 \mathrm{~kg}$, under 3 bar pressure and with 5 turns min ${ }^{-1}$ screw rotation speed, and under 10 bars, with $1 \mathrm{~m} \mathrm{~min}^{-1}$ sheet unfolding speed, a layers thickness of $0.03 \mathrm{~m}$, and a sheets width of $0.3 \mathrm{~m}$. The results of these trials are given in table 4 . The first noteworthy observation is an important washing off of sodium and potassium salts. The PBF and the SP displaced 70 and $45-$ to- $50 \%$ of these salts. 
The SP is among the solid/liquid separation simplest mechanical processes. Although, in terms of substrate drying, its performance appears slightly lesser than that of the PBF, the methane yield equivalent to the production of $\mathrm{COD}_{\mathrm{t}}$ was estimated respectively at $77.4 \mathrm{~L} \mathrm{CH}_{4} \mathrm{~kg}^{-1} \mathrm{VS}$ and at 24.6 $\mathrm{L} \mathrm{CH}_{4} \mathrm{~kg}^{-1} \mathrm{VS}$ for the SP and the PBF, which is nearly $60 \%$ less in substrate energy recuperation rate for the PBF than for the SP (Table 5). This clearly evidences the SP's mechanical effect upon extraction effectiveness and the methane potential of the stabilized phase. The screw's crushing role upon the filtration cage brings about the explosion of the algal cells. Although the PBF technique allows to get a better dehydration by applying a progressive pressure upon a bed of mud passing in a continuous flow under a pressure system, and although, at a pressure of 10 bars, no bending phenomenon is observed, the system has one major disadvantage: its sheets are very sensitive to pebbles' and gravels' presence. Its use would hence require at the start a stones' removal.

While the liquefaction juices extraction yield is characterized by the final residue dryness, it appears that this criterion is largely insufficient to translate the dehydration quality. The crushing's mechanical effect and the compression cause, where the SP is concerned, the evacuation through the filtration cage of an important quantity of particulate organic matter. The SS rate exceeded $100 \mathrm{~g} \mathrm{~L}^{-1}$ then when it was only about $20 \mathrm{~g} \mathrm{~L}^{-1}$ with the PBF. But, the grain size analysis shows nevertheless that freed grain sizes were relatively small, as they pass through the $128 \mu \mathrm{m}$ mesh sieve while only $50 \%$ are caught by the $16 \mu \mathrm{m}$ sieve. Under those conditions the plugging up risks of the bacterial filter in methanogenic phase appear rather limited.

Consequently, the PBF technology ought to be dropped in favor of the SP.

The budget of the hydrolysis, coupled to the pressing operation result was determined according to the two employed technologies (Table 5). As for the cake, it can be estimated at $2.3 \mathrm{t}$ for the PBF and $1.2 \mathrm{t}$ for the SP (density : 0.67), compared to the $14 \mathrm{t}$ of initial deposit (density : 0.60). That is consistent with the better recuperation of the organic matter in the juice for the SP.

Filtrates methanogenic fermentation

The methanogenic performances of the filtrate originating from the screw press were examined on a fixed bacterial bed reactor. The methanogenic fermentation is carried out at a temperature of $35^{\circ} \mathrm{C}$. The fermentation starts from a liquid hog manure's inoculum. The transition manure/algae filtrate proceeded under good conditions. Methane production increased as soon as the pure filtrate was introduced. The suspended matter rate was rather high, what did not prevent a good fermentation process from taking place. The sodium concentration did not perturb the methanogenic flora's activity. The $\mathrm{C} / \mathrm{N}$ ratio $(\mathrm{C} / \mathrm{N}=10)$ was fitted to production of a good quality biogas. Finally, the biological yield was $340 \mathrm{~L} \mathrm{CH}_{4} \mathrm{~kg}^{-1} \mathrm{VS}$ degraded, and the volumetric productivity reached $1.5 \mathrm{~m}^{3} \mathrm{CH}_{4} \mathrm{~m}^{-3}$ digester $\mathrm{d}^{-1}$ (Table 6).

\section{Delaying the methanisation process}

The juices' composition, largely metabolites fit for methanization, causes their conservation to be of short duration. Nevertheless, the juices' storage would permit to spread out and insure a correct feeding of the fermenter, in spite of an algae discontinuous supply. Therefore, juices from a filtrate obtained during tests with the screw-press were incubated in thermostatic chambers at $12^{\circ} \mathrm{C}$ and $20^{\circ} \mathrm{C}$, in order to mimic the storage conditions during Summer and Winter periods. The development of the soluble and total COD was studied during 105 days, with a sampling frequency of 15 days. After 60 days at $20^{\circ} \mathrm{C}$, the filtrate became so thick, that, from this period, sampling made necessary the level to be adjusted to its initial height with distilled water to allow correct homogenisation.

Quality of juice is function of three factors : evaporation, which concentrates the organic charge in the filtrate; volatilization of $\mathrm{COD}_{\mathrm{s}}$, which means losses in VFA; and degradation of particulate COD, which improves the ability of the juice to be digested.

The $\mathrm{COD}_{\mathrm{t}}$ decreased regularly, at 20 and $12^{\circ}$ respectively, from 44.63 and 47.26 to 9.19 and $12.71 \mathrm{~g} \mathrm{~L}^{-1}$, reported to the initial volume, what means a loss of 79 and $73 \%$ in a little more than three months. The particulate COD degradation kinetics was an exponential function, with exponential rates of degradation of $3.71 \%\left(r^{2}=0.08862\right)$ at $20^{\circ}$, and $3.45 \%\left(r^{2}=0.9685\right)$ at $12^{\circ}$. Thus the percentage of matter made soluble at experiment's end reached respectively $70 \%$ and $52 \%$. Matter degradation is more efficient at high temperatures. To the contrary, the volatilisation appeared not to be decreased 
by lowering temperature : at $20^{\circ}$, for one litre of initial juice, the sum of the amounts of initial $\mathrm{COD}_{\mathrm{s}}$ and particulate COD made soluble during the experiment was $36.62 \mathrm{~g}$, while the amount of COD volatilised was $35.44 \mathrm{~g}$; the corresponding figures at $12^{\circ}$ were 34.70 and $34.55 \mathrm{~g}$.

In these conditions, at the temperature of $20^{\circ} \mathrm{C}$, the $\mathrm{COD}_{\mathrm{s}}$ titer doubled after 45 days of storage due to evaporation and a degradation of about $50 \%$ of the particulate matter, passing then from $18 \mathrm{~g} \mathrm{~L}^{-1}$ to approximately $36 \mathrm{~g} \mathrm{~L}^{-1}$. However, in corrected value, viz. at a constant volume, the concentration remained steady at about 18 to $20 \mathrm{~g} \mathrm{~L}^{-1}$. At the $12^{\circ} \mathrm{C}$ temperature, the $\mathrm{COD}_{\mathrm{s}}$ concentration always maintained itself slightly under the initial $21 \mathrm{~g} \mathrm{~L}^{-1}$ value, until the $45^{\text {th }}$ day (13 in corrected value). Indeed, at $20^{\circ}$, during the first 45 days, the important quantity of matter made soluble compensated the VFA losses, where during this same period the $\mathrm{COD}_{\mathrm{s}}$ production represented only $60 \%$ of the losses for the filtrate kept at $12^{\circ} \mathrm{C}$.

Summing up, at $20^{\circ}$, particulate matter degradation allows to sustain during $1 \frac{1 / 2}{2}$ month the initial soluble COD quantity. Its load even doubles, as a result of evaporation. This load remains, on the other hand, identical at $12^{\circ}$. Beyond that time, a metabolites loss takes place, causing a lowering of the energetic yield and of the entire system's productivity. A 2-month maximal storing period appears thus allowable.

\section{Discussion}

The process' principle devised for Ulva sp. treatment is summarized in figure 4: the alga is hydrolysed in a storage pit, assimilated to an acidogenic reactor; the hydrolysis juices are recuperated by gravity followed by pressing of the deposit; methane is produced later from the liquefied organic matter in an anaerobic digester.

Extrapolation of the data given in tables 3 and 4 to processing a $1000 \mathrm{~m}^{3}$ algae deposit leads to the following figures. Fermentation in 3 months acidogenic phase produces $158 \mathrm{~m}^{3}$ of liquefaction juice and $1.8 \mathrm{t} \mathrm{COD}_{\mathrm{t}}\left(1.6 \mathrm{t} \mathrm{COD}_{\mathrm{s}}\right)$ naturally recuperated after storage. The deposit volume is reduced by a ratio of 4.5. The $220 \mathrm{~m}^{3}$ of predigested mud provide after pressing $192 \mathrm{~m}^{3}$ of pressing juice containing $10.9 \mathrm{t} \mathrm{COD}_{\mathrm{t}}\left(8.4 \mathrm{t} \mathrm{COD}_{\mathrm{s}}\right)$, and $75 \mathrm{~m}^{3}$ of cake with $42 \%$ of dry matter. In total, the $350 \mathrm{~m}^{3}$ of juice, $12.7 \mathrm{t}$ $\mathrm{COD}_{\mathrm{t}}$ would produce, if digested, $3660 \mathrm{~m}^{3}$ of methane, i.e. $40 \mathrm{MWh}$ (superior calorific value) or 36 $\mathrm{MWh}$ (inferior calorific value), equivalent to 3.1 tep, for a $\mathrm{COD}_{\mathrm{s}}$ purification rate of $95 \%$.

Hydrolysis plus pressing provide a sizeable mass )and volume reduction of solid residue deposits (factor of 30 and 13.3 respectively). The quality of residue obtained after pressing may be assimilated to a product of the organic enrichment type. This product provides also not negligible quantities of fertilizing elements that must be integrated in the fertilization balance sheet. The contributions per ton of product are evaluated to $182 \mathrm{~kg}$ of organic matter, wherefrom $64 \mathrm{~kg}$ in organic matter that can be turned into humus (with the hypothesis of an iso-humic coefficient nearly identical to that of household wastes compost), $8.4 \mathrm{~kg} \mathrm{~N}, 0.4 \mathrm{~kg} \mathrm{P}$, and $2.4 \mathrm{~kg} \mathrm{~K} \mathrm{O}_{2} \mathrm{O}$.

Salinity often limits utilization of algal-based products in agriculture. To attribute an economic value to the cake, we have therefore to be sure that its sodium content is compatible with use in agriculture. Its ratio $\mathrm{VS} / \mathrm{Na}$ equals 77 . As for the humic balance, it has been shown that the amount of humus destroyed is approximately $1.2 \mathrm{t} \mathrm{ha}^{-1} \mathrm{y}^{-1}$. Based upon an iso-humic coefficient of 0.35 , the balance would be in equilibrium with a supply of $4 \mathrm{t} \mathrm{VS}$ (without taking into account the return of organic matter generated by the plants themselves). The maintenance of the humus stock would require some $20 \mathrm{t}$ of cake per hectare and per year. At that dose, the supply in $\mathrm{Na}_{2} \mathrm{O}$ would be $63 \mathrm{~kg} \mathrm{ha}^{-1} \mathrm{y}^{-1}$, whereas the limit value is considered to be $110 \mathrm{~kg} \mathrm{ha}^{-1} \mathrm{y}^{-1}$ (Pelé, 1982). Sodium thus no longer is a limiting factor for product utilization in organic enriching or fertilizing as it was the case for fresh algae, of which it limited the spreading at $8 \mathrm{tha}^{-1} \mathrm{y}^{-1}$. It must be mentioned that the supply of nitrogen at this dose of $20 \mathrm{t}$ of cake per hectare and per year would be of $168 \mathrm{~kg} \mathrm{ha}^{-1} \mathrm{y}^{-1}$, quite in accordance with the need of the plants.

Utilization of the digestate as an open field fertilizer will avoid discharge of the nutrients-loaded effluent in nature. This solution however entails consideration of the constraints imposed by product salinity and to locate corresponding surfaces to be fertilized. Digestion wastes using in algae ponds appears as another potential solution enabling nutrients recycling through biomass production.

The needed investment to treat $25,000 \mathrm{~m}^{3}$ of harvested algae hovers around $0.6 \mathrm{M} €$ (Table 7). The income expected from the pressed cake ( $60 €$ per ton of organic matter), from the digestate as fertilizer ( $1 €$ per cubic meter) and from the biogas represent respectively $12,000 €, 7000 €$ and 
$30,000 €$. The presentation of the balance in gross return time permits to approach ten years. In such a case, the net return time is 20 years, but can be reduced to 10 with a $49 \%$ subvention. The development of this type of treatment remains thus linked to the need for government agencies to cover the extra cost of pollution abatement. This quick economic approach is interesting in that it shows clearly the limits of the Ulva treatment implementation. Such return times are unacceptable in our society. Thus, we have to think about the possibilities to diminish them.

With the screw press technique, which breaks the cells already degraded by the hydrolysis, it is possible to reduce the period of acidogenic fermentation down to 20 to 30 days (45 at the maximum, as shown by the results of the deposit hydrolysis followed during 3 months). The minimum time of deposition should nevertheless be precisely determined. In these conditions, the acidogenic fermenter building and the screw press could be amortized in a shorter time. $25,000 \mathrm{~m}^{3}$ are half of the "green tide" algae annually harvested in Brittany (Merceron, 1999). An itinerant press could be used in different locations of liquefaction reactors. Press availability would be a function of periodicity of needs.

As methanisation expenses are high, this step is, at present, more justified by the pollution abatement than by the income generated. Investment amortization and operation and maintenance costs are about tantamount to energy and digestate sale products (as energy cost increases).

An approach of utilization of laminariae for supplying, during 2 months, an existing digester normally functioning with liquid manure has been reported by Manclière (1985). The algae were introduced without washing or pretreatment, only ground and diluted so they could so they could be pumped. The presence of salt had not perturbed the bacterial flora nor afterwards good functioning of the digester. Another objection which could be raised is the presence of a significant amount of sulphur in Ulva, as sulfated oligosaccharides (Lahaye, 1998). Nevertheless, Nedergaard et al. (2002) showed the importance of sulfate reduction associated with thalli during decomposition. As hydrolysis and pressing juices are excellent substrates of methanisation, that neither their salinity is an obstacle for the good progress of the operation, nor the content in sulphur (removed during the hydrolysis step), a risk to have too high a proportion of $\mathrm{H}_{2} \mathrm{~S}$ in the biogas, they could be proposed to be used in existing digesters, all the more if their production be spread other several locations. The balance sheet of this heading would then become positive. The only problem will be to find existing methanisation plant sufficiently close to the drift algae stranding sites, something not always possible.

Sale of the juice may be means to fund hydrolysis and pressing equipment. As we have seen, after a storage of 45 days at $20^{\circ}$, juices became so thick that they had to be diluted before sampling. That was the expression of a significant load in VFAs. The COD (about 80\% VFA) load was $36 \mathrm{~g} \mathrm{~L}^{-1}$. Such a product would interest industry, as intermediary of chemical synthesis (Schoutteten, 2004), as substrate for feed production (Pelayo Ortiz et al., 1997) or fermentation (Uchida and Murata, 2004), or again as carbon source for denitrification process (Xu, 1996; Lim et al., 2000; Elefsiniotis, 2004).

Until now, amongst the different ways proposed to utilize Ulva in mass quantities, only composting and, on a very small scale, paper production have been implemented in some places and in small quantities. Methanisation attempts have collided with the fact that Ulva is not an energetic substrate easy to manipulate, thereby braking methanisation attempts. The approach herein described represents probably, at this time, the one offering the best compromise between methane yield, system productivity and treatment costs. Use simplicity and functioning flexibility are necessary to encourage setting up treatment stations.

\section{Acknowledgments}

This work was supported by a grant from the Agence Française pour la Maîtrise de l'Energie. We thank Anne-Lise Montéragioni for her assistance in typing the first manuscript. The help of Yves Picard for finalizing the figures was greatly appreciated. 


\section{References}

Baskerville RC, Komorek JA and Gale RS (1971) Effet of operating variables on filter press performance. Wat. pollut. control. 1971: 400-418.

Briand X and Morand P (1997) Anaerobic digestion of Ulva sp. 1. Relationship between Ulva composition and methanisation. J. appl. Phyc. 9: 511-524.

Charlier RH and Morand P (2005) Use, role and nuisance aspects of algae in coastal and related ecosystems: the importance of controlling eutrophication. In: Chircop A and McConnell M (eds) Ocean Yearbook 19. The University of Chicago Press, Chicago and London. pp 127-137.

de Jonge VN, Elliott M and Orive E (2002) Causes, historical development, effects and future challenges of a common environmental problem: eutrophication. Hydrobiologia 475/476: 1-19.

Elefsiniotis P, Wareham DG and Smith MO (2004) Use of volatile acids from an acid-phase digester for denitrification. J. Biotechnol. 114: 289-297.

Fletcher RL (1996) The occurrence of "green tides" - a review. In: Schramm W and Nienhuis PH (eds) Marine benthic vegetation. Recent changes and the effects of eutrophication. Springer-Verlag, Berlin, Heidelberg. pp. 7-43

Lahaye M (1998) NMR spectroscopic characterisation of oligosaccharides from two Ulva rigida ulvan samples (Ulvales, Chlorophyta) degraded by a lyase. Carbohydr. Res. 314: 1-12.

Lim SJ, Choi DW, Lee WG, Kwon S and Chang HN (2000) Volatile fatty acids production from wastes and its application to biological nutrient removal. Bioprocess engineering Berlin West 22: 543-545.

Manclère $\mathrm{P}$ (1985) Méthanisation des algues : de l'énergie à revendre? Équinoxe 3: 7-12.

Merceron M (1999) Inventaire des ulves en Bretagne - Année 1998. Rapport de synthèse (Study of Ulva proliferations in Brittany - Year 1998. Synthetic report). R. Int. DEL/99.15/Brest. Agence de l'Eau Loire-Bretagne, Orléans, France - IFREMER, Plouzané, France. 26 + II pp.

Missoni $G$ and Mazzagardi M (1985) Production of algal biomass in Venice Lagoon, environmental and energetic aspects. In: Palz W, Coombs J and Hall DO (eds) Energy from Biomass. 3rd EC Conference, Venice, 25-29 March 1985. Elsevier Applied Science, London. pp 384-386.

Morand $\mathrm{P}$ and Briand X (1996) Excessive growth of macroalgae: a symptom of environmental disturbance. Bot. mar. 39: 491-516.

Morand P and Briand X (1999) Anaerobic digestion of Ulva sp. 2. Study of Ulva degradation and methanisation of liquefaction juices. J. appl. Phyc. 11: 165-177.

Morand P and Merceron M (2004) Coastal eutrophication and excessive growth of macroalgae. In: Pandalai SG (ed.) Recent Res. Devel. Environ. Biol. 1. Research Signpost, Trivandrum, Kerala, India. pp 395-449.

Nedergaard RI, Risgaard-Petersen N and Finster K (2002) The importance of sulfate reduction associated with Ulva lactuca thalli during decomposition: a mesocosm experiments. J. exp. mar. Biol. Ecol. 275: 15-29.

Orlandini $M$ and Favretto $L$ (1988) Utilization of macroalgae in Italy for pollution abatment and as source of energy and chemicals. In Morand P, Schulte EH (eds) Aquatic Primary Biomass (Marine Macroalgae): Biomass Conversion, Removal and Use of Nutrients. I. Proceedings of the 1st Workshop of the COST48 Sub-Group 3. L'Houmeau, France. February 12-14, 1987. Commission of the European Communities, DG XII/F Biotechnology, Brussels. pp 25-28.

Pelayo Ortiz C, Steyer J-P and Bories A (1997) Carbon and nitrogen removal from wastewater by Candida utilis: kinetics aspects and mathematical modelling. Process Biochem. 32: 179-189.

Pelé E (1982) Inventaire des déchets valorisables en agriculture dans le département des Côtes-du-Nord. Chambre d'Agriculture, Saint-Brieuc, France. 110 pp.

Reid KC and Jackson P (1956) Non thermal drying of brown marine algae. J. Sci. Food Agric. 7: 291-300.

Schoutteten F (2004) Valorisation non alimentaire des agro-ressources. Fiche technique agroindustrie. CRCI/ARIST Champagne-Ardenne, Châlons-en-Champagne, France. 6 pp.

Uchida M and Murata M (2004) Isolation of a lactic acid bacterium and yeast consortium from a fermented material of Ulva spp. (Chlorophyta). J. appl. Microbiol. 97: 1297-1310.

Wilkinson L (1963) Nitrogen transformations in a polluted estuary. Int. J. Air Water Poll. 7: 737-752.

Xu Y (1996) Volatile fatty acids carbon source for biological denitrification. J. environ. Sci. 8: 257-268. 


\section{Tables}

Table 1. Starting conditions and results of pressing of Ulva hydrolysis muds by tray press.

\begin{tabular}{|c|c|c|c|c|}
\hline \multirow{2}{*}{ Characteristic } & \multirow{2}{*}{ Unit } & \multicolumn{3}{|c|}{ Trial } \\
\hline & & 1 & 2 & 3 \\
\hline Initial mass & $g$ & 1006 & 2001 & 1000 \\
\hline Initial pressure & bar & 5 & 5 & 25 \\
\hline Initial dryness & $\%$ & 19.4 & 20.5 & 17.7 \\
\hline Dryness after filtration & $\%$ & 20.1 & 21.4 & 19.3 \\
\hline Dryness at $\mathrm{t}=5 \mathrm{~min}$ of pressing & $\%$ & 35.9 & 30.7 & 53.6 \\
\hline Final juice mass after dripping & $\mathrm{g}$ & 558.5 & 857.5 & 767.0 \\
\hline Final dryness & $\%$ & 38.5 & 32.7 & 61.7 \\
\hline Juice dryness & $\%$ & 4.11 & 4.20 & 4.13 \\
\hline
\end{tabular}


Table 2. Parameters of the different industrial equipment trials, and characteristics of the hydrolysed algae deposits, algae cakes after treatment and recuperated juices.

\begin{tabular}{|c|c|c|c|c|c|c|c|c|c|c|c|c|}
\hline \multirow[t]{2}{*}{ Equipment } & \multirow[t]{2}{*}{$\begin{array}{l}\text { Ulva deposit } \\
\text { age (month) }\end{array}$} & \multirow[t]{2}{*}{$\begin{array}{l}\text { Rotation speed } \\
\text { (turns/min) }\end{array}$} & \multirow[t]{2}{*}{$\begin{array}{l}\text { Pressure } \\
\text { (bar) }\end{array}$} & Deposit & \multicolumn{3}{|c|}{ Characteristics } & \multicolumn{3}{|c|}{ Filtrate } & \multirow{2}{*}{\multicolumn{2}{|c|}{$\begin{array}{l}\mathrm{COD}_{\mathrm{t}} \mathrm{COD}_{\mathrm{s}} \\
\left.\mathrm{L}^{-1}\right)\left(\mathrm{g} \mathrm{L}^{-1}\right)\end{array}$}} \\
\hline & & & & $\begin{array}{l}\text { Masse } \\
\quad(\mathrm{kg})\end{array}$ & $\begin{array}{l}\text { Masse } \\
(\mathrm{kg})\end{array}$ & $\begin{array}{l}\text { TS } \\
(\%)\end{array}$ & $\begin{array}{l}\text { Volume } \\
\text { (L) }\end{array}$ & $\begin{array}{l}\mathrm{EY}^{*} \\
(\%)\end{array}$ & $\begin{array}{c}\text { TS } \\
\left(g^{-1}\right)(g L\end{array}$ & $\begin{array}{l}S S \\
\left.L^{-1}\right)(g\end{array}$ & & \\
\hline Centrifuge & 4 & $4000(2000 \mathrm{~g})$ & - & 5 & - & - & - & 30 & - & - & - & - \\
\hline \multirow[t]{5}{*}{ Screw press } & 3 & 3 & $\begin{array}{l}2.2 \\
3 \\
4 \\
10\end{array}$ & $\begin{array}{l}140 \\
110 \\
125 \\
125\end{array}$ & $\begin{array}{l}37 \\
20 \\
29 \\
26\end{array}$ & $\begin{array}{l}35 \\
38 \\
39\end{array}$ & $\begin{array}{r}103 \\
90 \\
96\end{array}$ & $\begin{array}{l}89 \\
99 \\
93 \\
96\end{array}$ & $\begin{array}{l}93 \\
95 \\
78\end{array}$ & $\begin{array}{l}40 \\
64 \\
66\end{array}$ & $\begin{array}{l}23 \\
44 \\
56\end{array}$ & $\begin{array}{l}15 \\
33 \\
25\end{array}$ \\
\hline & & 5 & $\begin{array}{l}2.2 \\
3 \\
5.8\end{array}$ & $\begin{array}{l}125 \\
105 \\
125\end{array}$ & $\begin{array}{l}30 \\
27 \\
25\end{array}$ & $\begin{array}{l}34 \\
38 \\
42\end{array}$ & $\begin{array}{r}95 \\
78 \\
100\end{array}$ & $\begin{array}{l}92 \\
90 \\
97\end{array}$ & $\begin{array}{l}86 \\
74 \\
79\end{array}$ & $\begin{array}{l}56 \\
61 \\
68\end{array}$ & $\begin{array}{l}65 \\
33 \\
48\end{array}$ & $\begin{array}{l}34 \\
15 \\
22\end{array}$ \\
\hline & & 8 & $\begin{array}{l}3 \\
5.8\end{array}$ & $\begin{array}{l}115 \\
120\end{array}$ & $\begin{array}{l}21 \\
22\end{array}$ & $\begin{array}{l}38 \\
41\end{array}$ & $\begin{array}{l}94 \\
98\end{array}$ & $\begin{array}{l}99 \\
99\end{array}$ & $\begin{array}{l}108 \\
118\end{array}$ & $\begin{array}{l}74 \\
81\end{array}$ & $\begin{array}{l}47 \\
49\end{array}$ & $\begin{array}{l}34 \\
31\end{array}$ \\
\hline & & 10 & $\begin{array}{l}2.2 \\
3 \\
5.8 \\
10\end{array}$ & $\begin{array}{l}120 \\
115 \\
115 \\
110\end{array}$ & $\begin{array}{l}43 \\
23 \\
21 \\
21\end{array}$ & $\begin{array}{l}33 \\
38 \\
40 \\
38\end{array}$ & $\begin{array}{l}97 \\
92 \\
94 \\
89\end{array}$ & $\begin{array}{l}89 \\
99 \\
99 \\
98\end{array}$ & $\begin{array}{r}115 \\
103 \\
146 \\
91\end{array}$ & $\begin{array}{l}61 \\
97 \\
61\end{array}$ & $\begin{array}{l}33 \\
60 \\
48 \\
52\end{array}$ & $\begin{array}{l}25 \\
38 \\
25 \\
22\end{array}$ \\
\hline & 7 & 3 & $\begin{array}{l}1 \\
2\end{array}$ & $\begin{array}{l}1000 \\
1000\end{array}$ & $\begin{array}{l}458 \\
547\end{array}$ & $\begin{array}{l}40 \\
34\end{array}$ & $\begin{array}{l}542 \\
453\end{array}$ & $\begin{array}{l}72 \\
60\end{array}$ & $\begin{array}{l}125 \\
148\end{array}$ & $\begin{array}{l}118 \\
148\end{array}$ & $\begin{array}{l}50 \\
33\end{array}$ & $\begin{array}{r}11 \\
9\end{array}$ \\
\hline
\end{tabular}




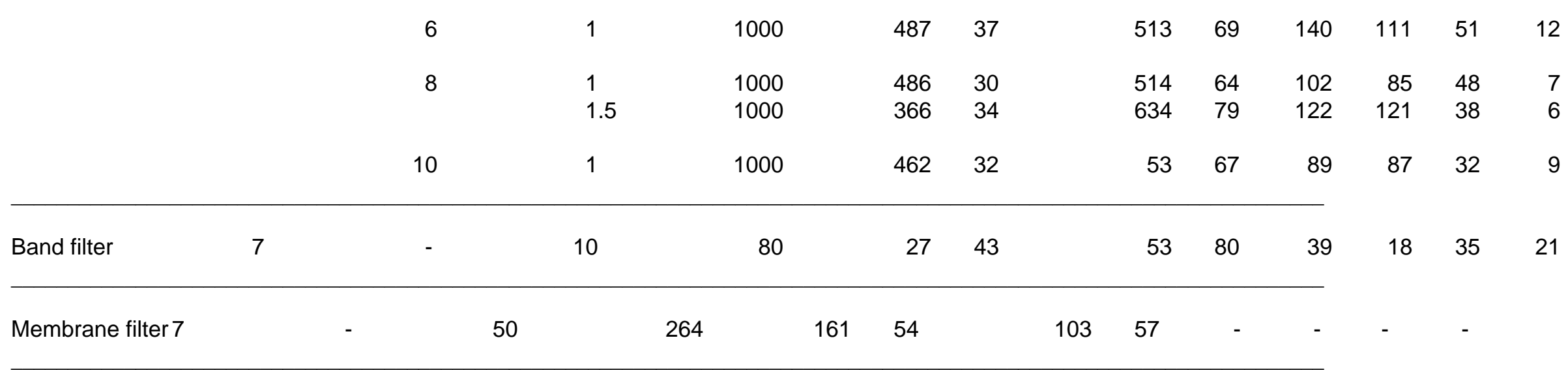

${ }^{\star} \mathrm{EY}$ : Extraction yield of the soluble COD 
Table 3. Evolution of a 14,000 kg Ulva deposit during a 3-month hydrolysis.

\begin{tabular}{|c|c|c|c|c|c|c|c|}
\hline Week & 0 & 1 & 2 & 4 & 6 & 8 & 12 \\
\hline Density & 0.60 & 0.42 & 0.60 & 0.60 & 1.03 & 1.06 & 1.10 \\
\hline Total solids* & 12.1 (1.4) & $17.1(4.9)$ & $19.1(4.2)$ & $19.1(1.9)$ & $23.5 \quad(1.6)$ & $21.4 \quad(6.3)$ & $17.3(0.52)$ \\
\hline Volatile solids* & 64.8 (4.8) & 42.5 (11.0) & 37.4 (8.7) & 43.3 (4.8) & 40.4 (1.1) & $39.9(11.0)$ & 40.4 (8.9) \\
\hline Carbon * & 20.9 (3.9) & $20.8 \quad(4.5)$ & 14.4 (5.9) & $20.8 \quad(2.5)$ & $20.4 \quad(3.4)$ & $24.4 \quad(2.2)$ & $21.7 \quad(2.1)$ \\
\hline Total nitrogen (NTK)* & $1.87(0.14)$ & $1.33(0.27)$ & $1.02(0.29)$ & $1.58(1.05)$ & $1.44(0.17)$ & $1.93(0.34)$ & $1.95(0.17)$ \\
\hline Phosphorus* & $0.21(0.06)$ & $0.19(0.06)$ & $0.23(0.07)$ & $0.21(0.08)$ & $0.27(0.06)$ & $0.33(0.09)$ & $0.30(0.05)$ \\
\hline Sodium* & $4.12(1.42)$ & $2.85(0.67)$ & $2.48(0.82)$ & $3.33(1.05)$ & $2.34(0.23)$ & $3.05(0.75)$ & $1.82(0.82)$ \\
\hline Potassium* & $1.65(0.59)$ & $1.11(0.35)$ & $1.22(0.33)$ & $1.70(0.26)$ & $1.31(0.32)$ & $1.41(0.37)$ & $0.92(0.25)$ \\
\hline
\end{tabular}

*Data are expressed in \% WW for total solids, and in \% TS for the following ones.

Standard deviations are mentioned between parentheses $(n=6)$. 
Table 4. Characteristics of the products obtained by pressing with screw press (SP) $125 \mathrm{~kg}$ of Ulva submitted to a 3-month hydrolysis, or $1050 \mathrm{~kg}$ with pressing band filter (PBF).

\begin{tabular}{|c|c|c|c|c|}
\hline \multirow{2}{*}{$\begin{array}{l}\text { Equipment } \\
\text { Characteristics }\end{array}$} & $\mathrm{SP}$ & PBF & \multirow[t]{2}{*}{ SP } & PBF \\
\hline & Cake & Filtrate & & \\
\hline Wet weight (kg) & 26 & 430 & 99 & 620 \\
\hline $\mathrm{COD}_{\mathrm{t}} *$ & - & - & 52 & 21 \\
\hline $\mathrm{COD}_{\mathrm{s}}$ * & - & - & 40 & 19 \\
\hline Total solids* & 42 & 48 & 108 & 60 \\
\hline Volatile solids* & 43 & 40 & 41 & 19 \\
\hline Carbon * & 22.8 & 22.6 & 22 & - \\
\hline Total nitrogen (NTK)* & 2.00 & 1.55 & 2.0 & 1.8 \\
\hline Phosphorus* & 0.09 & 0.18 & 0.5 & 0.6 \\
\hline Sodium* & 0.77 & 0.98 & 3.1 & 3.6 \\
\hline Potassium* & 0.55 & 0.49 & 1.4 & 1.9 \\
\hline
\end{tabular}

*Data are expressed, for cake, in \% WW for total solids, and in \% TS for the following determinants, and, for juices, in $\mathrm{g} \mathrm{L}^{-1}$. 
Table 5. Balance sheet of recovery of $\mathrm{COD}_{\mathrm{t}}, \mathrm{NH}_{4}{ }^{+}$and energy during hydrolysis and pressing steps (screw press : SP; pressing band filter : PBF).

\begin{tabular}{|c|c|c|c|c|c|}
\hline \multirow[t]{2}{*}{ Characteristics } & \multirow{2}{*}{$\begin{array}{l}\text { Acidogenic } \\
\quad \text { fermentation }\end{array}$} & \multirow{2}{*}{$\begin{array}{c}\text { Pressing } \\
\text { SP }\end{array}$} & \multicolumn{3}{|c|}{ Sum for the two steps filter } \\
\hline & & & PBF & $\mathrm{SP}$ & PBF \\
\hline Juice (L/50 kgVS) & 168 & 204 & 166 & 372 & 334 \\
\hline COD (kg/50 kgVS) & 1.9 & 11.6 & 3.5 & 13.5 & 5.4 \\
\hline $\mathrm{NH}_{4}^{+}(\mathrm{kg} / 50 \mathrm{kgVS})$ & 0.05 & 0.18 & - & 0.23 & 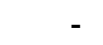 \\
\hline $\mathrm{CH}_{4}$ equivalent $\left(\mathrm{L} \mathrm{kg}^{-1} \mathrm{VS}\right)$ & 13.4 & 77.4 & 24.6 & 90.8 & 38.0 \\
\hline$E Y^{*}$ & 3.4 & 19.4 & 6.1 & 22.8 & 9.5 \\
\hline
\end{tabular}

${ }^{\star}$ EY : Extraction yield of the soluble COD 
Table 6. Characteristics of the anaerobic digestion of an Ulva sp. filtrate.

Characteristics Experimental conditionsInfluent Effluent Purification rate

\begin{tabular}{|c|c|c|c|c|}
\hline Retention time $(\mathrm{d})$ & 10 & - & - & - \\
\hline Loading rate $\left(\right.$ COD L L ${ }^{-1}$ dig. $\left.d^{-1}\right)$ & 5.2 & - & - & - \\
\hline $\mathrm{pH}$ & - & 6.2 & 7.3 & - \\
\hline $\mathrm{COD}_{\mathrm{t}}\left(\mathrm{g} \mathrm{L}^{-1}, \mathrm{~g} \mathrm{~L}^{-1}\right.$, and $\left.\%\right)$ & - & 52 & 11 & 79 \\
\hline $\mathrm{COD}_{\mathrm{s}}\left(\mathrm{g} \mathrm{L}^{-1}, \mathrm{~g} \mathrm{~L}^{-1}\right.$, and $\left.\%\right)$ & - & 40 & 2 & 95 \\
\hline VS $\left(\mathrm{g} \mathrm{L}^{-1}, \mathrm{~g} \mathrm{~L}^{-1}\right.$, and $\left.\%\right)$ & - & 45 & 21 & 53 \\
\hline $\begin{array}{l}\text { Methane content in biogaz (\%) } \\
\text { Methane yields }\left(\mathrm{m}^{3} \mathrm{~kg}^{-1}\right)^{\star}\end{array}$ & 81 & - & - & - \\
\hline $\mathrm{Y}_{\mathrm{CH}_{4} / \mathrm{COD}_{\mathrm{o}}}$ & 0.29 & - & - & - \\
\hline $\mathrm{Y}_{\mathrm{CH}_{4}}{ }^{/} \mathrm{COD}_{\mathrm{r}}$ & 0.34 & - & - & - \\
\hline Methane productivity $\left(L^{-1}\right.$ dig. $\left.d^{-1}\right)$ & 1.5 & - & - & - \\
\hline
\end{tabular}

* o for introduced, $r$ for removed 
Table 7. Processing of $25,000 \mathrm{~m}^{3}$ of green algae from the Bay of Lannion : economic balance.

\begin{tabular}{ll} 
Expenses & $\begin{array}{l}\text { Investment for acidogenic reactor and forced recovery } \\
\text { of the juices by pressing }\end{array}$ \\
$\begin{array}{l}\text { Investment for methanogenic digester } \\
\left(165 \mathrm{~m}^{3} \text { fixed film }\right)\end{array}$ & $€ 400,000$ \\
\hline Provision & $€ 600,000$ \\
Functioning and maintenance & $€ 15,000$ \\
Personnel & $€ 15,000$ \\
TOTAL & $€ 90,000$
\end{tabular}

$\begin{array}{ll}\text { Receipts } & \text { Pressed cake (organic improver : } 45-60 € \mathrm{t}^{-1} \mathrm{VS} \text { ) } \\ \text { Digester output (fertilizer : } 1 € \mathrm{~m}^{-3} \text { ) } & € 7,000 \\ \text { Biogas } & € 30,000 \\ & \\ \text { TOTAL } & € \mathbf{5 0 , 0 0 0}\end{array}$




\section{Figures}

A

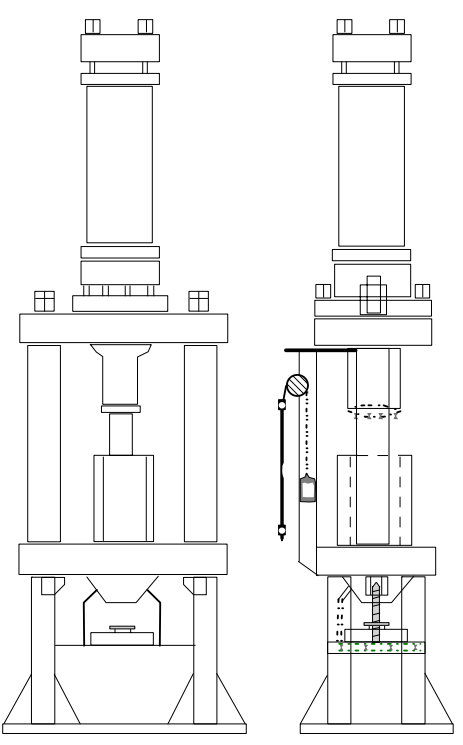

B

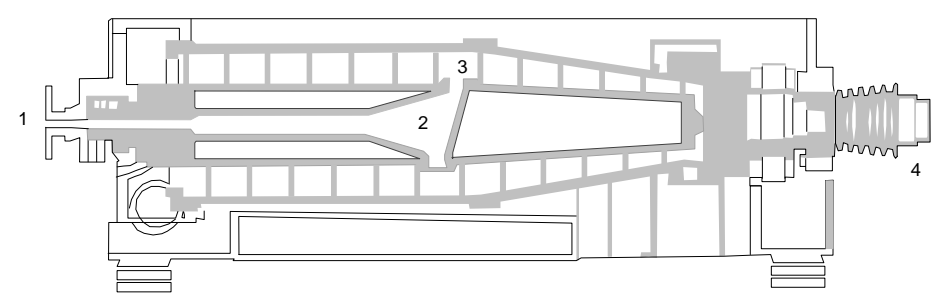

E

C

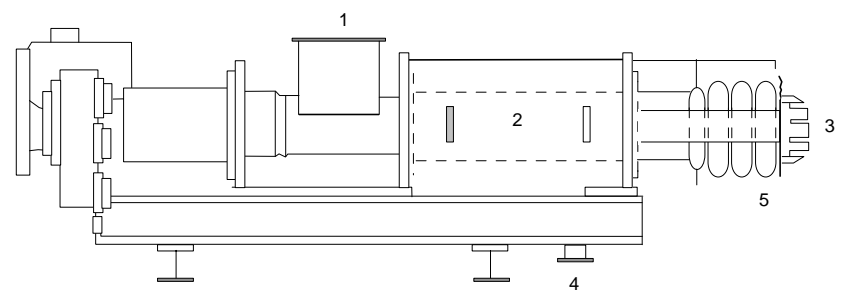

D
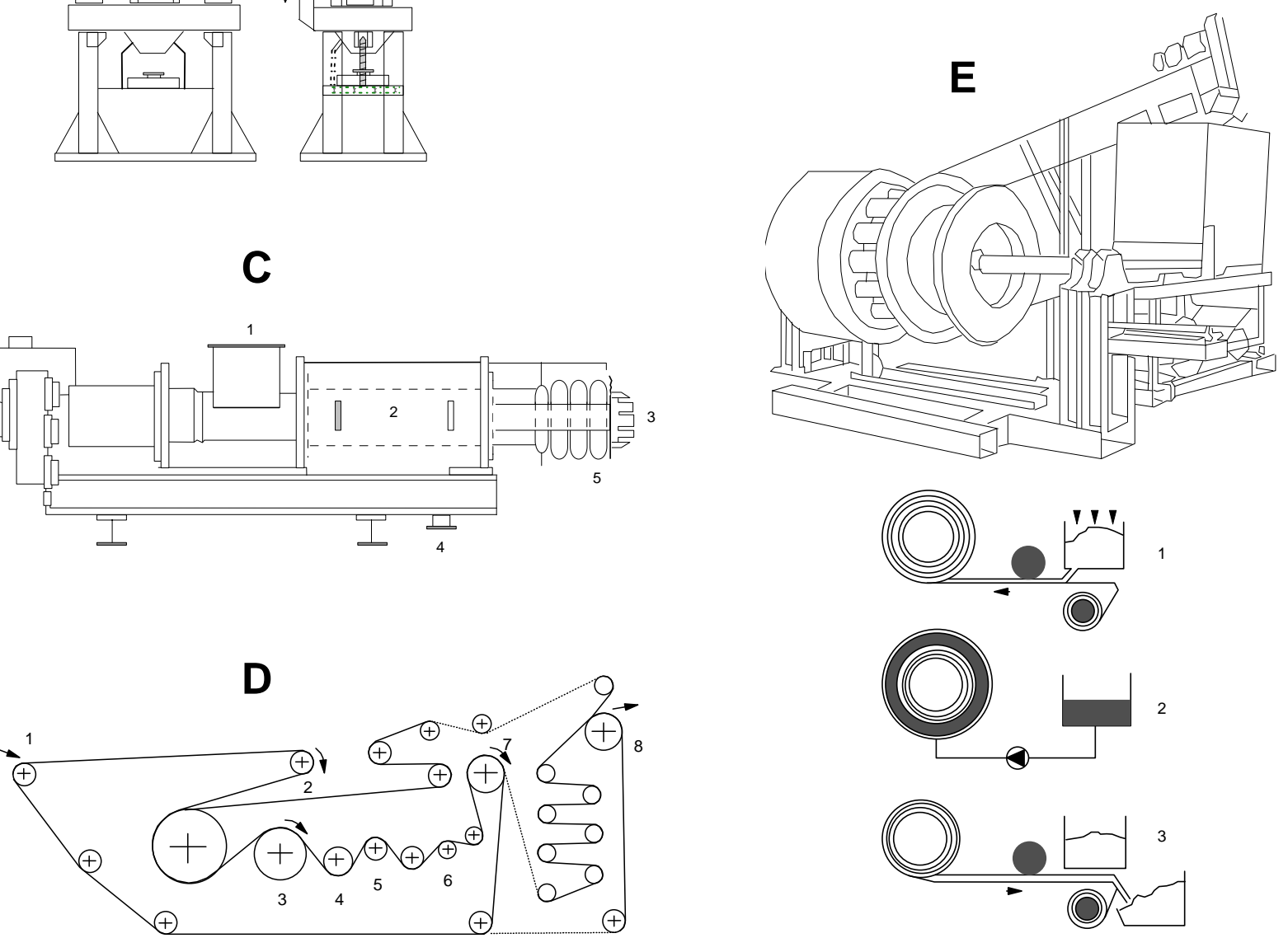

Figure 1. Some devices used for solid/liquid separation. A: Tray press. B: Centrifuge 1 , mud entry; 2 , rotating distributor; 3 , forwarding screw; 4 , cake exit. C: Screw press - 1 , mud entry; 2 , filtration cage; 3: shutter cone; 4, filtrate exit; 5 , cake exit. D: Pressing band filter - 1 , mud entry; 2 , filtration cloth; 3 : roller with holes; 4 , full roller; 5 , cloth tension roller; 6 , medium pressure roller; 7 , driving roller; 8 , cake exit. E: membrane filter - 1, mud spooling; 2, pressing; 3: unspooling of hyper-pressed mud. 

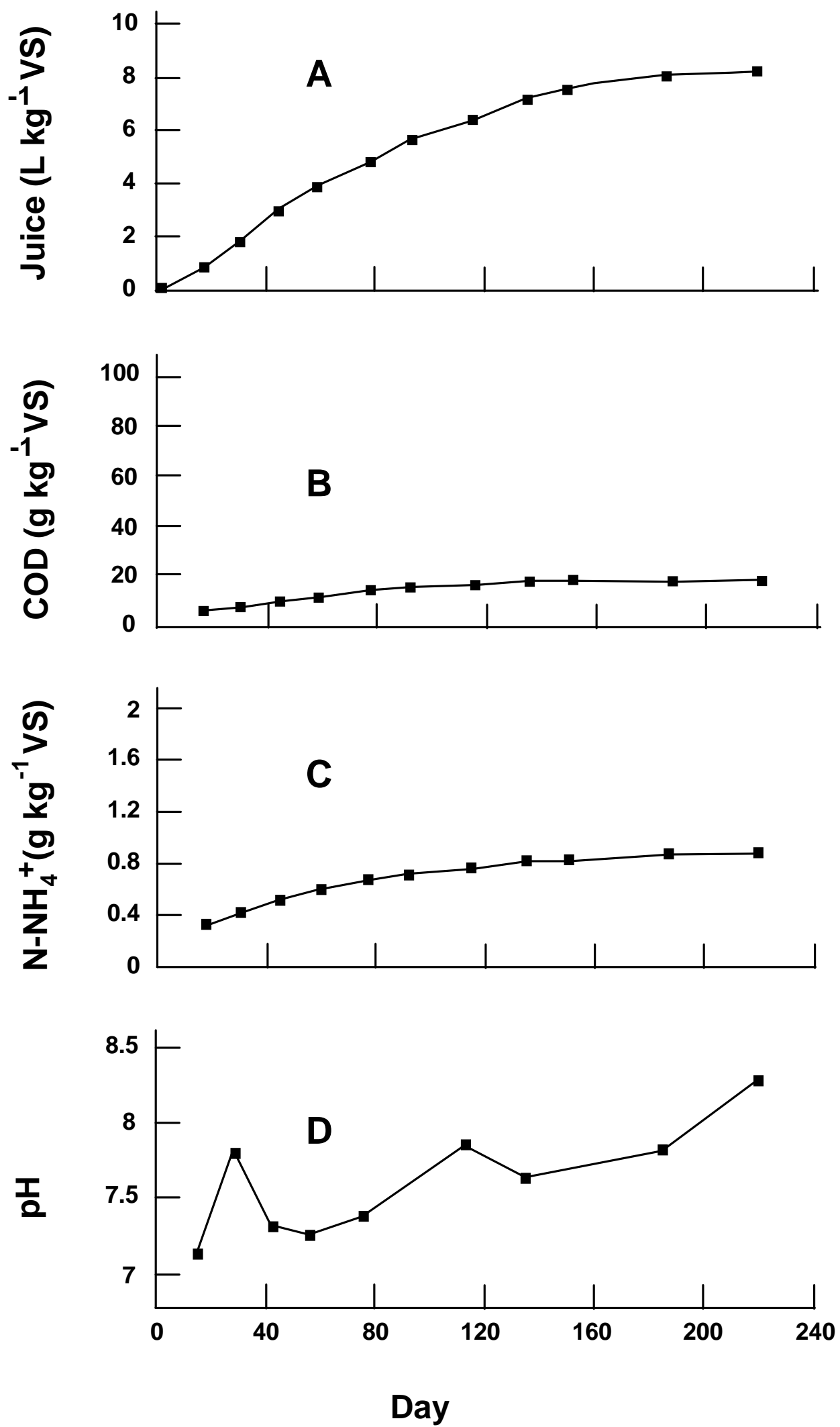

Figure 2. Production of juice $(A)$ during Ulva hydrolysis in a real size fitted out pit, evolution of the sum of the chemical oxygen demand (B) and ammoniacal nitrogen (C) drained in the juice, and $\mathrm{pH}$ value (D) in the juice. 

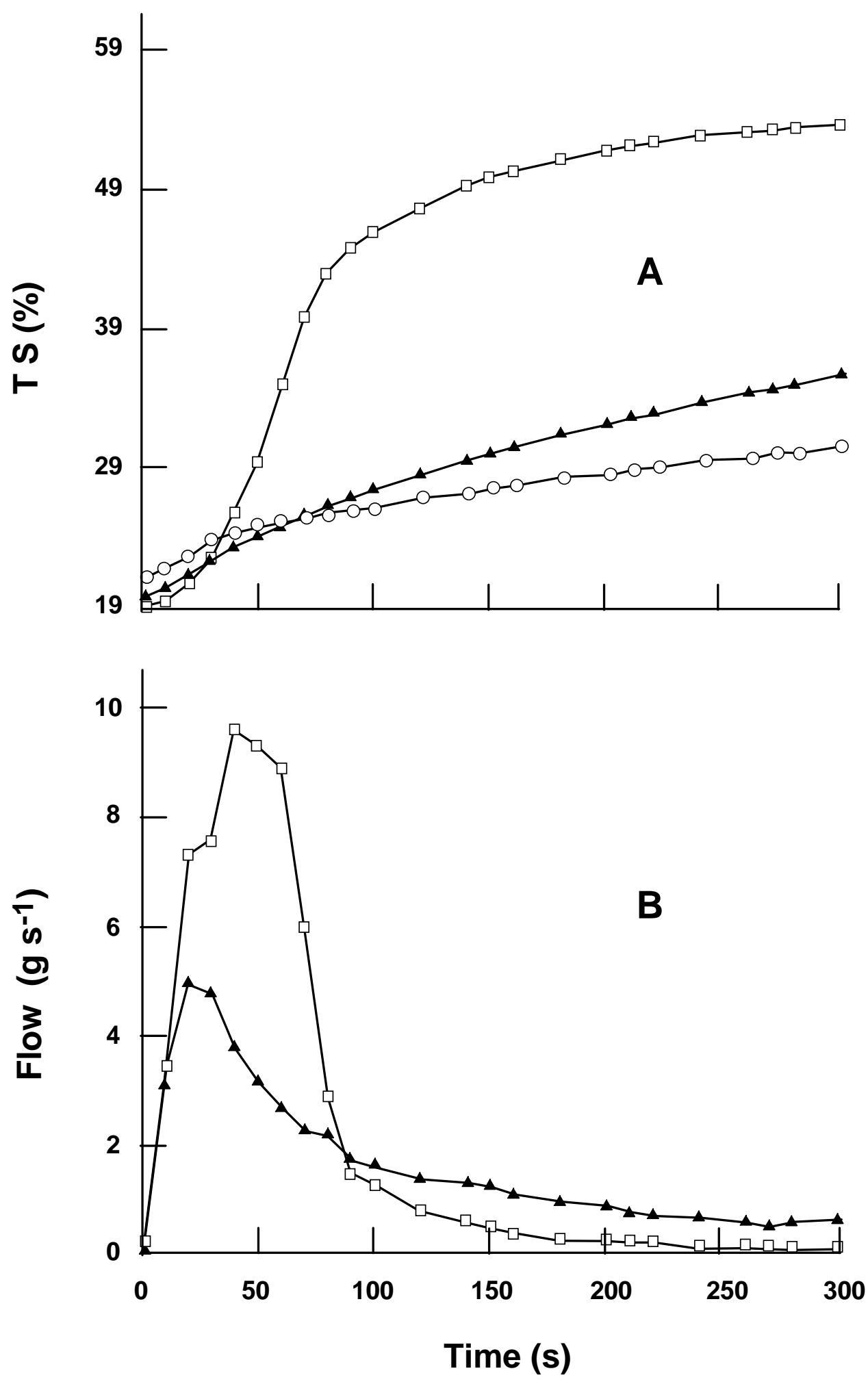

Figure 3. Layers' thickness and pressure influence upon cake's dryness evolution $(A)$, and pressure influence upon the juice production rate during the pressing cycle (B): trial 1,5 bar and $1006 \mathrm{~g}$ of wet Ulva mud $(\sigma-\sigma)$; trial 2, 5 bar and $2001 \mathrm{~g}$ of wet Ulva mud $\left(\mathrm{O}_{-} \mathrm{O}\right)$; trial 3, 25 bar and $1000 \mathrm{~g}$ of wet Ulva mud $(\square-\square)$. 


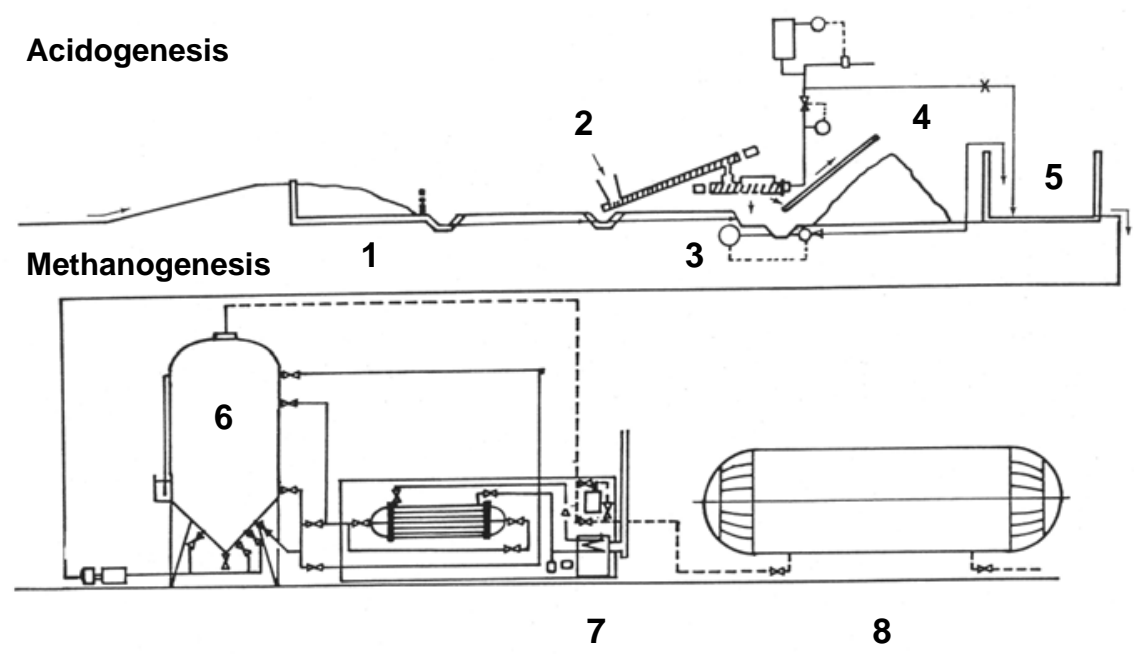

Figure 4. Synoptic scheme of Ulva sp. treatment by separation of acidogenic and methanogenic phases. 1: Acidogenic reactor. 2: Predigested muds. 3: Screw press. 4: Pressed muds. 5: Storing tank of hydrolysis juices. 6: Methanogenic reactor. 7: Biogas boiler. 8: Gasometer. 